\title{
Development of state ideology as a basis for improving the executive power
}

\author{
Vitaly Goncharov ${ }^{1, *}$, Tatiana Mikhaleva ${ }^{2}$, Grigory Vasilevich $^{2}$, Sergey Balashenko ${ }^{2}$, Jacek \\ Zalesny $^{3}$, and Artem Pukhov ${ }^{2}$ \\ ${ }^{1}$ Kuban State Agrarian University Named after I.T. Trubilin, Russia \\ ${ }^{2}$ Belarusian State University, Republic of Belarus \\ ${ }^{3}$ University of Warsaw, Republic of Poland
}

\begin{abstract}
This article provides a constitutional and legal analysis of the problems of the formation and development of state ideology as the basis for optimizing the system of executive power in the Russian Federation. According to the authors, without the formation of a state ideology in the Russian Federation, it is impossible to ensure the development of society and the state. The work has developed and justified a system of measures to remove obstacles in the formation and development of state ideology in Russia; the purposes, tasks and parameters of the ideological basis of Russian statehood are formulated, which will ensure the implementation of the optimization of the executive power system in the country, the largescale modernization of its economy and the qualitative improvement of the living standards of the population of the Russian Federation.
\end{abstract}

\section{Introduction}

The Institute of Executive Power in the Russian Federation is widely analyzed in the scientific works of N.Yu. Khamaneva, O.E. Kutafin, V.V. Grib, L.Yu. Grudtsyna, V.E. Chirkin and several other authors. These works provide the basis for the analysis of the theoretical content of the executive branch in relation to its social essence. However, the share of researches that sanctify the problems of the formation and development of state ideology as the basis for optimizing the system of executive power in the Russian Federation is extremely small. In this regard, the main purpose of this research is a comprehensive study of the problems of the formation and development of state ideology as the basis for optimizing the system of executive power in the Russian Federation, in order to expand and clarify the conceptual and categorical apparatus of the science of constitutional law in the sphere of executive power, forming an integrated the concept of the optimal organization and exercise of executive power in Russia, and the subject of research is the regulatory of formation and functioning of the executive power system in the country, as well as scientific views on the problems of formation and development of state ideology as a basis for optimizing the system of executive power in the Russian Federation as a constitutional and legal category.

\footnotetext{
*Corresponding author: niipgergo2009@mail.ru
} 


\section{Materials and Methods}

This article in the process of cognition of state-legal phenomena were used: a) General scientific methods (formal-logical, systemic, structural-functional, concrete-historical); b) General logical methods of theoretical analysis (analysis, synthesis, generalization, comparison, abstraction, analogy, modeling, etc.); c) private scientific methods (technical and legal analysis, specification, interpretation, etc.) (Zalesny, Goncharov, 2019: 129-142; Zalesny et all., 2019: 51-61; Zalesny, Goncharov, 2020a: 1-6; Goncharov et all., 2020a, 7890; Goncharov et all., 2020b, 93-106; Moros, Goncharov, 2020, 114-128; Zalesny, Goncharov, 2020b: 1-10).

\section{Results and Discussion}

It seems that the preservation by the Russian Federation of state sovereignty and independence in the 21 st century is impossible without the maximum concentration of efforts of society and the state on the path of structural modernization of the country's economy, its transfer to a new innovative basis, accompanied by a qualitative increase in the standard of living of the majority of the Russian population. It is naive to assume that Russia, which has more than thirty percent of the world's natural resources and a rapidly declining population, worn out by a production and housing and communal fund, will be able to withstand the future redistribution of the world if it does not overcome a qualitative and quantitative development gap in relation to states that are currently global world leaders (USA and China). The situation is aggravated by a number of internal social negative factors: the low life expectancy of the population (in men it is below the retirement age); an increase in the number of persons with disabilities; a catastrophic increase in the number of legal and illegal migrants, most of whom are ethnically and culturally not ready for assimilation in Russia (for example, the number of migrants from China is growing); drop in education, health; the growth of drug addiction, alcoholism, prostitution, the cult of an immoral lifestyle.

All these factors allow us to conclude that the preservation of Russian statehood is only possible provided that the country overcomes the above development gap with world economic and political leaders in the shortest possible time (the logic of historical development devotes only 3-5 years to this for the Russian Federation, which will probably be the last peaceful years in world history, and will precede the global redistribution of spheres of influence on the planet) (Website, 2020a), and the economy and the social sphere of the country's life should be translated It's not a catch-up, but a leading type of development, which will have to be provided economically with a significantly higher level of labor productivity (than in the USA, China and the European Union) and the prevalence of innovative technologies over traditional ones; in socio-cultural terms - the most severe suppression of immoral behavior and lifestyle and the imposition of high moral ideals, creating the most free conditions for the life and work of citizens, and opportunities for them to reveal their abilities.

Domestic and world history shows that such a concentration of the efforts of society and the state is possible only if the unity of views and worldview of its ruling social classes and groups, their subordination to a certain idea that is positive socially useful. Thus, the joint activity of society and the state should be meaningful and focused in nature and rest on a certain ideological basis. Within the framework of the state mechanism, this ideological basis can be partially expressed and fixed in certain program documents, be of a systemic nature, taking the form of a state ideology (Poyarkov, 2009a: 19-23; Martishin, 2013: 3444). 
In modern domestic and foreign scientific and educational literature there is no consensus in the definition of state ideology. This is partly caused by the confusion and diversity of definitions in the world of philosophy broader notion of "ideology". As rightly said on this occasion T. Eagleton, the author of the fundamental work "Ideology", the lack of unity in the definition of the concept of ideology due to the fact that "the notion of ideology is a text that is woven from all of the tissues of different concepts, often contradictory, and therefore more important to determine what should be left and what can be thrown away in each of them than to combine them artificially into some Grand global theory of ideology" (1991: 1-2). So, in his opinion, in the world of philosophy there are several basic definitions of ideology: a) as a process of production of ideas, knowledge, signs and values in social life; b) as a set of ideas characteristic of certain social groups and classes; c) as a system of ideas that allows the state to legitimize political power; d) as a system of false ideas which help to legitimize the state political power; e) systematically distorted communications; e) as forms of thought motivated by social interests; f) as a necessary social illusion; g) as effective-centric orientation of faith, convictions; h) as situation reasoning, and authority; i) as a confusion of linguistic and phenomenal reality; j) as the process of transformation of social ideas in actual reality (Eagleton, 1991: 1-2). The Russian philosopher A. Zinoviev noted that ideology itself is just a product of the invention of professional ideologists, and historically promising real ideology ("guiding purpose") can, by definition, be derived only from an analysis of the course of history, "from a clearly defined theory" (Zinoviev, 2020).

Due to the variety of definitions of the concept of ideology, the approaches to the definition of the concept of state ideology differ significantly. A number of authors consider the state ideology from a spiritual and cognitive standpoint, understanding it as a spiritual and practical formation in which the interests of the people and the state are expressed and defended in all their complexity and inconsistency (Yakovlev, 2001: 25). Some scholars believe that the concept of state ideology should be considered as the principle of property management adopted in this particular state (Russian, 2020). According to other authors, "an understanding of ideology should be linked to the historical situation. Since crisis is one of the structural features of modern times, the reconstruction of the ideal type of ideology ... must begin with a historical correlation between the crisis consciousness of modern times and the century of classical ideologies" (Matz, 1992: 130142).

Some Russian authors, noting the fact that the country's constitution prohibits the existence of any ideology as state or mandatory, consider the state ideology as a combination of the country's constitution and all official laws of the state, as well as moral ideology (philosophy of good and future state). Moreover, under the basic spheres of moral ideology, they understand moral values, relations between society and power, interethnic politics, relations between faiths, social class inequality, the attitude of society towards nature, the debate and health of a nation, which are embodied in the minds of people through two levels of propaganda: visual-figurative and logical (Sytnik, 2020). Some philologists consider state ideology as a state-mediated system of views, ideas that characterize a social group, class, political party or society (Dictionary, 2020). A number of other philologists believe that state ideology is a certain worldview, a system of views and ideas that prevail in a politically organized society (Ushakov, 2017: 163, 298).

It seems that the state ideology has a number of signs: firstly, it is a combination of ideas, concepts, judgments that make up a belief, belief and various theories (Sorokin, 2003: 483), and in its totality - a worldview that is characteristic of members of society (or rather, the prevailing social classes and groups, as well as their unions) at a certain stage of its development; secondly, state ideology, as a rule, is imposed on society by a certain part of it that is interested; thirdly, it affects all aspects of the life of society and the state; 
fourthly, state ideology represents a certain ideological quintessence of dominant economic relations (property management relations) in society and the state; fifthly, it consolidates a certain epistemological ideal, which society and the state should strive for in its development, and thereby, is a certain organizational, mobilization and informational basis for this development; sixthly, the state ideology, despite the fact that due to its doctrinal consolidation, is partly static in nature, is constantly being modernized, dynamically developing due to the constant change in social relations in the world as a whole and in a particular state in particular. Thus, state ideology should be understood as a dynamically developing worldview, imposed on society by the dominant social classes and groups, as well as their unions, affecting all aspects of the life of society and the state, which is a certain ideological quintessence of dominant economic relations (property management relations), fixing a certain epistemological ideal, to which society and the state should strive in their development, and are its organizational, mobilization and informational basis for this development.

However, the ideological foundations of any states that have steadily existed throughout the history of mankind represented a kind of compromise between the class and universal aspects of the worldview (Theory, 2001: 51), which was dictated by the need for politically dominant classes not only to satisfy their interests, but also to create conditions for the preservation and development of statehood in general. Even at the earlier stages of social development (in the era of slave and feudal states), the ruling classes were forced to extend the mechanisms of state protection to unprivileged social classes and strata, including slaves and serfs, as the latter, in turn, were a certain irreplaceable economic condition for the existence and development of the state as such. Since its emergence as a socio-political phenomenon, state ideology in Russia has undergone a series of transformations during the historical development of our state. From the standpoint of historical materialism, based on the formational criterion for changing society and the state (Horina, 2020), state ideology in Russia has undergone a stormy path, having passed successively the stages of slaveholding, feudal, bourgeois (capitalist), socialist, and now again capitalist development. From the standpoint of social progress in our country, successively replacing each other, various types of conservative, revolutionary (for example, Marxist socialist ideology), progressive and reactionary state ideology dominated (Marxist-Leninist, 1971: 15). Certain stages of historical development were characterized by the presence of a religious component in state ideology (up to 1917).

It seems that the process of developing state ideology in our country, right up to the current state of the ideological foundations of Russian statehood, taking into account all of the factors listed above, has gone through the following crucial stages: 1) the foundation of Kievan Rus; 2) the adoption of Christianity; 3) the heyday of Kievan Rus; 4) the period of the Mongol-Tatar yoke and feudal fragmentation of the country; 5) the acquisition of independence and sovereign status by Russia under the slogan "Moscow the third Rome"; 6) the collection of Russia; 7) troubled times; 8) Peter's breakthrough; 9) the competition of "Westernism" and "Slavophilism" in choosing the paths of development of Russia; 10) the era of the "Red Empire" (Website, 2020b). Obviously, in the course of Russian history, there was a direct correlation between successes in the development of the Russian state and the existence of a well-formed and carefully implemented ideological foundation of Russian statehood. The success of the Kiev Grand Dukes, uniting Russia under the banner of Orthodoxy as a state-paternalistic ideology, and the great Petrovsky breakthrough at the turn of the 17-18th centuries, which gave the Russian state ideology an imperial character and indicated the need to overcome the qualitative and quantitative lag, are also associated with the presence of a positive state ideology. countries from Western competitors, and a socialist state ideology that inspired several generations of citizens of the country with the possibility of realizing the practice of centuries-old ideals of goodness and justice and 
which provided ample opportunities for citizens to exercise their abilities. At the same time, periods of lack of state ideology in Russia, or its radical breakdown, were accompanied by an unprecedented economic recession in the country, impoverishment and cultural and moral degradation of its population (for example, in the "troubled" times preceding the accession of the Romanov dynasty during the revolution of 1917 and the ensuing civil war).

Recent human history has been characterized by significant changes in the formation and development of the ideological foundations of modern states. First of all, this was reflected in the leveling of national features of the state worldview, globalization and internationalization of the system of views and ideas on which the principles of organization and activity of the state mechanism in modern countries are based. In words, we are talking more and more about universal human values, human rights and freedoms as the fundamental value and foundation of modern statehood. In fact, the formal propaganda of "universal values" does not prevent the political elite of the developed Western states from receiving good dividends from the connivance of world smuggling of weapons, drugs, prostitution, illegal occupation of countries (Iraq, Afghanistan), robbing them, and bombing rebellious nations and peoples (Yugoslavia). In every possible way, not only the manifestation of nationalistic and patriotic views in assessing the functions and tasks of the state is condemned, but also the foundations of the existence of nations and states as sovereign and independent international entities are undermined.

After all, the existence of a sovereign and independent state is unthinkable without the presence of three independent and independent components: people, territory and state mechanism. The legal system of a country must guarantee that its people will indeed be the bearer of sovereignty and the only sources of power in the state. The power of the people should have certain spatial boundaries - the territory of the country, and its implementation in the interests of the people should be delegated to the state mechanism, which should have sovereignty from any internal and external influences except for one entity delegating authority to it - the people. After the collapse of the USSR (in the era of the unipolar political map of the world with the dominant role of the United States), two processes proceeded in parallel. On the one hand, the US leadership in every possible way suppressed any manifestations of the sovereignty and independence of countries, both in the international arena and in determining the directions of domestic development (especially in countries that formed on the site of the Warsaw Treaty states). On the other hand, US leaders themselves have lost the ability to independently determine the vectors of state development, becoming a kind of puppets in the hands of international financial tycoons, transnational corporations and informal planetary organizations. Thus, the state mechanisms of most countries in determining the direction of state development, which is one of the foundations of state ideology, are increasingly dependent on the opinion of the US ruling elite, which, in turn, is part of the global elite system, a kind of planetary superelite. The territory of countries is increasingly ceasing to be the spatial boundaries of their state sovereignty. On the one hand, the role of the territory of countries in their independence is weakening as a result of political globalization and integration processes (for example, in Europe, the borders of countries within the European Union are already partly formal). On the other hand, a number of countries are imposed in national legal systems as a priority international legal norms. The constitutions of many states have fixed the provisions that, in the event of a conflict of national legal norms with international law, the latter shall be applied. In addition, a huge number of developing countries formed a significant number of branches of law, using the numerous "model", "standard" codes, laws, and rules developed by international organizations.

The institutional foundations of the sovereignty of nations and peoples are substantially undermined. First of all, over the past half century, the institution of the family as the primary unit of society and its cementing social principle has been intensively destroyed. 
This undermining is carried out in a number of directions: firstly, the destruction of the moral principles of the family and marriage is strongly promoted (homosexual relations, feminism, "free love", etc. are encouraged); secondly, "animal" individualism is encouraged, which consists in the fact that a person, the satisfaction of his desires and needs, is presented as the sole end in itself and the value of human existence. The national features and the ability to independently identify themselves are etched from the people's memory (which is only worth the cancellation of the column "nationality" in the passports of citizens of Russia and a number of foreign countries).

The current state of the ideological foundations of Russian statehood is distinguished by a number of significant problems of formation and development regarding the use of this tool in the process of centralizing power in the country:

Firstly, the current Constitution of the country in Part 2 of Article 13 denies the possibility of establishing any ideology as state or mandatory. But in this case, it is unclear what to do with the norms of the Constitution itself and the current legislation of the country, which, in essence, constitute the doctrinal consolidation of certain philosophical principles in society that are systemic in nature, that is, they are a form of expression and consolidation of state ideology. And the denial of the obligatory nature of any ideology casts doubt on the obligatory nature of the Basic Law of the country. It seems that this norm of the Constitution of the Russian Federation only reflected the fears of the first President of Russia regarding the possibility of a communist revenge and was fixed as an obstacle to the return of this ideology as the dominant one in the country.

Secondly, the public administration system in the Russian Federation is quite strongly and universally "infected" with corruption, cronyism, bribes, especially at the regional level. And the consolidation of any ideology without a detailed cleaning of the state and municipal apparatus from these negative phenomena will mean only an illusory character, a fictitious state ideology itself. She will act as the next "Potemkin Village" to create in the eyes of the townsfolk honesty, decency and paternalistic nature of the power-keeping elite.

Thirdly, the formation of a state ideology is also complicated by the fact that immorality in society, neglect of centuries-old moral and ethical standards have become the norm, and not an exception, not only among representatives of the power or financial and economic elite, but also among broad sections of any classes and social groups of society. The moral and cultural degradation of society is not an ideal basis for the formation and development of any more or less positive state ideology. Obviously, state ideology in this case can only be formulated by narrow groups of the population and imposed on society as a whole.

Fourthly, there is a significant number of external factors that impede the formation of state ideology in our country (various forms of opposition in this matter to other countries, supranational and supranational entities), since the lack of state ideology in Russia since the early 90 s of the 20th century is quite clear showed the countries that are our competitors and outspoken opponents that only in this state the Russian Federation can never achieve the modernization of its economy and qualitatively to improve the living standards of the population, while maintaining a similar anyway deideologization Russian society and the state is waiting for the collapse and disappearance from the political map of the world as a sovereign and independent state.

Fifthly, a serious problem of the formation of state ideology in the country is the lack of desire to form it among the country's leadership. For example, President of the Russian Federation Vladimir Putin in the first years of his presidency often expressed concern about Russia's lack of ideology, noting that this primarily affects the upbringing of the younger generation. The issues of state ideology were, to one degree or another, addressed in almost all of his messages to the Federal Assembly of the Russian Federation (Message, 2005). However, today the question of formulating official ideology remains open. As for the financial and economic elite of the country, it is completely alien to the issues of the 
formation of state ideology due to the fact that Russia is considered by it as a place of relatively easy fund raising. In addition, the families of most of them have long left the borders of the Russian Federation.

Sixthly, the process of forming a state ideology is complicated by the presence of ethnic and cultural alienation of the society's elite from the majority of the country's population.

Seventhly, the forcing of state ideology should be preceded by a rather complicated and lengthy process of choosing a political and philosophical basis for it. Indeed, at present, in the world, in addition to the traditional types of state and political ideology (fascism, nazism, communist (marxist-leninist), liberal, conservative, religious), there are also many non-classical forms (neo-Marxism, neoliberalism, neoconservatism, neo-nazism) (Horina, 2020).

However, as mentioned above, history devotes a relatively modest period of time to the question of choosing the political and philosophical foundations of Russian state ideology.

To eliminate these problems of formation and development of state ideology (in order to use this instrument in the process of centralization of power in the country), the following measures should be taken:

Firstly, it is necessary to consolidate in the Constitution of the Russian Federation and current legislation the possibility of the formation and implementation of state ideology, outlining its foundations, which, as a number of authors rightly notes, allows for the successful development of civil society in our country (Poyarkov, 2009b: 1643-1647).

Secondly, corruption and cronyism should be brutally eradicated from the state machinery, and these processes should be fixed as one of the elements of the state ideology of the Russian Federation. (Avakyan, 2019: 18-21; Kiseleva, 2018: 61-69)

Thirdly, it is necessary to create a mechanism to counter the negative ideological impact on the territory of Russia, suppressing the illegal and anti-state activities of foreign and international organizations. In this regard, according to some scientists, the issue of ensuring the ideological security of the Russian Federation is gaining great attention (Poyarkov, 2009c: 4-8; Vasilevich et all., 2019: 85-92).

Fourthly, the government should be centralized. In order to avoid the growth of centrifugal tendencies and separatism at the level of subjects of Russia, it is necessary to ensure the rotation of regional elites, suppressing cronyism and corruption merging of regional leaders and the criminal community (Alekhnovich, 2003: 14-17; Tikhomirov, 2007: 99-105). At the same time, when developing the state ideological basis, it is necessary to take into account the multinational, multiconfessional composition of the Russian Federation (Fundamentals, 2001).

Fifthly, it will be necessary to involve the broad masses of the population in the processes of forming the ideological basis of the Russian state and fixing it in the current legislation, ensuring the creation of a mechanism for public control over the state power (Sinyugin, 2014: 26-28; Starodubova, 2013: 130-136; Goncharov, Kovaleva, 2009a: 7275).

Sixth, a radical examination of the domestic political and financial elite should be conducted to determine its purification from corrupt officials, agents of influence of foreign and international organizations, states and transnational companies acting to the detriment of the interests of the Russian Federation. (Kalinin, 2020: 14-23; Maslovskaya, 2020: 4652)

After the collapse of the USSR and the formation of the Russian Federation as a sovereign and independent state, a radical change in ideological priorities and preferences took place in our country, and, above all, in the country's power elite, which was systemic in nature:

First, in the sphere of organizing political life in the state and society, the power of one political party "CPSU" and one ideology (communist) was replaced by political diversity 
and multi-party system, enshrined in Part 3 of Article 13 of the Constitution of the Russian Federation (Martyshin, 2006: 31-37; Postnikov, 2013: 5-12), liberalism of state ideology, which led our country, according to several authors, to ideological bankruptcy (Oseychuk, 2014: 27-35).

Secondly, in the sphere of organizing religious life in the state and society, propaganda on behalf of the state of atheism as a denial of the existence of God has been replaced by the secularization of Russian statehood in Article 14 of the Constitution of the country with a ban on establishing any religion as state or mandatory (Goncharov, Kovaleva, 2009b: 1821).

Thirdly, in the sphere of organizing the state mechanism in the country, the unity and indivisibility of power at all its levels in the person of the Councils of People's Deputies and their executive committees has been replaced by the constitutional consolidation of the principle of separation of powers, both horizontally (legislative, executive and judicial), and vertically (to state (Federal and regional) and municipal (Articles 10, 11 and 130 of the Constitution of the Russian Federation) (Alekhnovich, 2003: 14-17; Cherepanov, 2003).

Fourthly, in the sphere of state participation in the regulation of economic relations in society, the general control of the state and the ban on private ownership of the means of production were replaced by constitutionally fixed liberal theses on state non-interference in economic matters, according to which the state mechanism is assigned the role of a "night watchman" (Article 34, 35 and other Constitution of the country).

Fifthly, in modern Russia, a number of social guarantees are not legislatively fixed (for example, the obligation of the state to provide employment for any able-bodied citizen of the country; the right to free universal education, health care). The ideology of equality of citizens in the rights to receive social benefits from the state and their accessibility was replaced by the cultivation of theses on the enrichment of citizens as the only source of ensuring the realization of their growing needs (Sokolova, Spiridonova, 1995).

Such a change in ideological guidelines led to significant negative consequences for the viability and development of society and the state (Poyarkov, 2009a: 4-8). First of all, there was a significant drop in the economy in the country, the state lost a number of modern innovative technologies (for example, computer design) and the ability to reproduce them. In addition, the demolition of the old model of the state mechanism was accompanied by a rampant increase in corruption among the authorities, especially at the regional and municipal levels, when officials began to perceive their official powers as a kind of business, and the state budget as a feeder for its development. The standard of living of the majority of the population fell significantly, resulting in a significant drop in the life expectancy of citizens of the country, especially men, of rapid depopulation (due to high mortality and low birth rates). Religious diversity and the "washing of hands" by the state from its regulation led to the creation of thousands of sects of an anti-state, anti-people and anti-human orientation, in which millions of our fellow citizens are already involved. Moreover, a significant part of such sects is actively coordinated and financed by the special services of foreign states. Significantly increased the level of crime in the country, she was younger. Organized crime is becoming increasingly intertwined with the state mechanism, since criminal authorities are actively "going into power". Monstrous proportions have reached property stratification in society, which is 2-3 times higher than similar indicators in the United States and other developed countries. Decentralization processes are still strong in the country, the separatist aspirations of regional elites, especially in the republics within the Russian Federation, to secede from the country, its artificial collapse similar to the collapse of the USSR in 1991, are not broken. The state mechanism is no longer capable of either setting global tasks for society, which are necessary for modernizing the economy and socio-political relations in the country (without which Russia will not remain as a sovereign and independent state), or implementing them 
in the optimal time frame. Corruption and immorality of power is associated with the loss of cultural-moral and moral-ethical guidelines in society. Alcoholism, drug addiction, prostitution, laziness, a low level of production culture are becoming widespread in modern Russia.

Thus, the lack of a systematic approach to understanding the need for the formation and development of the ideological foundation of Russian statehood (Poyarkov, 2009c: 19-23) casts doubt on the very possibility of preserving the Russian Federation as a sovereign and independent state (Levakin, 2002: 16-26). The practice of the existence of Russia since 1991 has shown that without the presence of a state ideology, the institutions of civil society themselves, which hold the multinational state mechanism into a single system, are also not viable (Poyarkov, 2009b: 1643-1647).

Thus, in the formation of the ideological basis of the Russian state in the future there are two ways.

The first path provides an opportunity for the preservation and development of Russian statehood, its sovereignty, independence, the creation of conditions for the reproduction of the indigenous peoples of Russia, the improvement of their standard of living, cultural and moral education, and spiritual growth.

In this regard, the state ideology of Russia will consist in building a sovereign, independent innovative state with accelerated development, which will be achieved: a) a high level of morality, morality, possibly propaganda of the moral values of official religions: Orthodoxy, Islam, Buddhism and Judaism (spiritual and moral aspect); b) with the definition of an official political ideology with emphasis on national (Fundamentals, 2001) and patriotic (Goncharov, 2008: 11-13) features of the Russian state (political and ideological aspect); c) the legal system should be based on the promotion of the maximum satisfaction of the rights, freedoms and legitimate interests of citizens of the country, but within the framework of observing the high moral standards of Russian statehood with a strong and independent judiciary (Bondar, 2005: 15-30; Pavlikov, 2014: 84-92), total control of the state mechanism by society (legal aspect) (Goncharov - Kovaleva, 2009a: 7275).

The second way will mean a gradual loss by the people and the state mechanism of their sovereignty and independence, due to the collapse of the economy, the military-industrial complex, the extinction of the indigenous population, its cultural, moral and spiritual degradation. This path can be enclosed in any elegant covers: conservatism, propaganda of a "rule of law with liberal values", etc.

As a result, the state-power elite, and society itself, is faced with an alternative: either in the shortest possible time, the state will form and implement the ideological basis for the preservation and development of Russian statehood (which will act as a kind of matrix for optimizing the system of public administration and modernizing the Russian economy) or Russia as a Federal state is waiting for the collapse and disappearance from the political map of the world. Such changes are possible (as world history shows) either from above (by the ruling elite), which is preferable for Russia because of their bloodless and peaceful nature, or from below (through bloody revolutionary upheavals). The latter scenario is most likely, although the authorities make it appear that reforms are being carried out on this issue.

At the same time, research shows that the majority of Russian citizens support the consolidation of the state ideology in the Constitution: (Poyarkov, 2009c: 4-8) 
Table 1. The attitude of the citizens of the Russian Federation to the institutionalization of state ideology in the Constitution.

\begin{tabular}{|c|c|c|c|}
\hline $\begin{array}{c}\text { Age categories of } \\
\text { Russian citizens }\end{array}$ & $\begin{array}{c}\text { Support the } \\
\text { consolidation of the } \\
\text { state ideology in the } \\
\text { Constitution (in \% of } \\
\text { the total number) }\end{array}$ & $\begin{array}{c}\text { They do not support } \\
\text { the consolidation of the } \\
\text { state ideology in the } \\
\text { Constitution (in \% of } \\
\text { the total number) }\end{array}$ & $\begin{array}{c}\text { Undecided on the } \\
\text { choice (in \% of } \\
\text { the total } \\
\text { number) }\end{array}$ \\
\hline $18-30$ years old & 31 & 29 & 40 \\
\hline $31-40$ years old & 35 & 27 & 38 \\
\hline $41-50$ years old & 44 & 22 & 34 \\
\hline $51-60$ years old & 51 & 19 & 30 \\
\hline 61 years and older & 55 & 16 & 29 \\
\hline
\end{tabular}

\section{Conclusions}

An analysis of the prevailing ideological foundations in modern stable and successfully developing states (for example, the USA, China) shows that the most promising of them are communist ideology (in China); building a state on the basis of religious norms, mainly Islam (in a number of countries in the Arab region); the gradually emerging ideology of postindustrial totalitarianism (in the USA and European Union countries) (Legal, 2003). It seems that the optimal ideology that will allow any country in the 21 st century to maintain sovereignty and independence will be the one that will ensure the maximum mobilization of the efforts of society and the state on the path of modernizing its economy, improving the cultural, moral, ethical and socio-economic standard of living of the population.

\section{References}

1. S.O. Alekhnovich, Law and right 1, 14-17 (2003)

2. S.A. Avakyan, Journal of the Belarusian State University. Law 3, 18-21 (2019)

3. N.S. Bondar, Journal of Russian law 11, 15-30 (2005)

4. V.A. Cherepanov, Constitutional and legal basis for the division of state power between the Russian Federation and its subjects. Monograph (MZ-PRESS, Moscow, 2003) ISBN 5-94073-061-2

5. Dictionary. (2020) http://www.ozhegov.ru/slovo/15374.html

6. T. Eagleton, Ideology (Z.N.Y., 1991)

7. Fundamentals of national and federal relations (Moscow, 2001) ISBN 5-7729-0070-6

8. V.V. Goncharov, History of state and law 16, 11-13 (2008)

9. V.V. Goncharov, L.I. Kovaleva, On institutions of public control of executive power in the Russian Federation 1, 72-75 (2009)

10. V.V. Goncharov, L.I. Kovaleva, Modern law 4, 18-21 (2009)

11. V. Goncharov, J. Zalesny, S. Balashenko, G. Vasilevich, A. Pukhov, Wisdom 16(3), 78-90 (2020) https://doi.org/10.24234/wisdom.v16i3.332

12. V. Goncharov, J. Zalesny, S. Balashenko, G. Vasilevich, A. Pukhov, Wisdom 15(2), 93-106 (2020) https://doi.org/10.24234/wisdom.v15i2.333

13. G.P. Horina, Ideology as an element of the culture system (2020) http://www.lib.ru

14. S.A. Kalinin, Journal of the Belarusian State University. Law 3, 14-23 (2020)

15. T.M. Kiseleva, Journal of the Belarusian State University. Law 3, 61-69 (2018) 
16. Legal systems of the world: an Encyclopedic reference (NORMA Publishing house, Moscow, 2003) ISBN: 5-89123-725-3

17. I.V. Levakin, Law and politics 10, 16-26 (2002)

18. O.V. Martishin, State and law 12, 34-44 (2013)

19. O.V. Martyshin, State and law 10,31-37 (2006)

20. Marxist-Leninist general theory of state and law. Historical types of state and law (Moscow, 1971)

21. T.S. Maslovskaya, Journal of the Belarusian State University. Law 3, 46-52 (2020)

22. U. Matz, Polis 1-2, 130-142 (1992)

23. Message of the President of the Russian Federation to the Federal Assembly of the Russian Federation dated 25.04.2005. Russian newspaper, 86 (2005)

24. Y.F. Moros, V. Goncharov, Wisdom 15(2), 114-128 (2020) https://doi.org/10.24234/wisdom.v15i2.354

25. V.I. Oseychuk, State and law 11, 27-35 (2014)

26. S.G. Pavlikov, State and law 1, 84-92 (2014)

27. A.E. Postnikov, Journal of Russian law 5, 5-12 (2013)

28. S.Yu. Poyarkov, Politics and society 2, 19-23 (2009)

29. S.Yu. Poyarkov, Law and politics 8, 1643-1647 (2009)

30. S.Yu. Poyarkov, National security 2, 4-8 (2009)

31. Russian idea and state ideology of Russia in the light of social-humanism (2020) http://social-gumanizm.narod.ru/statji2.htm\#9

32. V.Yu. Sinyugin, Administrative law and process 7, 26-28 (2014)

33. R.I. Sokolova, V.I. Spiridonova, "Power Technology" (philosophical and political analysis) (Institute of philosophy of the Russian academy of sciences, Moscow, 1995) ISBN: 5-201-01871-8

34. P.A. Sorokin, Hunger as a factor. The impact of hunger on people's behavior, social organization, and social life (Moscow, 2003) ISBN 5-87444-186-7

35. O.E. Starodubova, Journal of Russian law 2, 130-136 (2013)

36. M. Hytnik, How does the state begin? http://www.np.kz/old/2002/42/mnenie.html

37. Theory of state and law: Course of lectures (Jurist, Moscow, 2001)

38. Yu.A. Tikhomirov, Journal of Russian law 2, 99-105 (2007)

39. D.N. Ushakov, Large explanatory dictionary of the modern Russian language (Publishing house "Bucolic", "Publisher ROOSA", Vladivostok, 2017) ISBN 9785990973527

40. Website of Mikhail Delyagin (2020) http://www.delyagin.ru

41. Website of the newspaper "Tomorrow" (2020) http://www.zavtra.ru

42. G.A. Vasilevich, A.A. Kashirkina, A.N. Morozov, Journal of the Belarusian State University. Law 2, 85-92 (2019)

43. A.I. Yakovlev, State ideology (Kaluga, 2001)

44. J. Zalesny, V. Goncharov, Future Human Image 12, 129-142 (2019) https://doi.org/110.29202/fhi/12/12

45. J. Zalesny, V. Goncharov, M. Savchenko, Wisdom 2(13), 51-61 (2019) 
46. J. Zalesny, V. Goncharov, Journal of Legal, Ethical and Regulatory Issues 23(2), 1-6 (2020)

47. J. Zalesny, V. Goncharov, Journal of Legal, Ethical and Regulatory Issues 25(5), 1-10 (2020)

48. A. Zinoviev, Ideology of the party of the future (2020) http://www.lib.ru 